\title{
OBOWIĄZEK STOSOWANIA \\ PRZEZ PRZEDSIĘBIORCÓW WEWNĘTRZNYCH PROCEDUR ANTYKORUPCYJNYCH W ŚWIETLE PROJEKTU USTAWY O JAWNOŚCI ŻYCIA PUBLICZNEGO
}

\section{WSTĘP}

Od ponad roku trwają w Polsce prace legislacyjne nad ustawa o jawności życia publicznego, określanej również mianem ustawy antykorupcyjnej. W datowanym na 8 stycznia 2018 r. projekcie ustawy ${ }^{1}$ (obok uregulowań dotyczących m.in. oświadczeń majątkowych, zasad dostępu do informacji publicznej, jawności w procesie stanowienia prawa, prowadzenia lobbingu czy instytucji tzw. sygnalisty) znalazły się przepisy mające służyć przeciwdziałaniu praktykom korupcyjnym. Zapisy projektowanej ustawy regulujące tę materię już na etapie prac legislacyjnych zdają się wzbudzać pewne kontrowersje ${ }^{2}$. Jej celem miała być walka z korupcją i nadużyciami swoich stanowisk przez przedstawicieli władzy publicznej. Zakładana ratio legis projektowanej ustawy zasługuje jednak na pełną aprobatę. Zgodnie ze stanowiskiem projektodawcy wyrażonym w uzasadnieniu ustawy celem zawartych w niej przepisów ma być wzmocnienie instytucjonalnej i społecznej kontroli władzy publicznej i osób ja sprawujacych ${ }^{3}$. Skutkiem jej wejścia w życie powininny być, według projektodawcy, wzrost efektywności w zarządzaniu państwem oraz silne wzmocnienie mechanizmów antykorupcyjnych w Polsce ${ }^{4}$. W marcu 2018 r. wstrzymano procedowanie projektu tej ustawy.

Niniejsze opracowanie zwraca uwagę na liczne wady legislacyjne, jak i problemy praktyczne, które moga pojawić się w zakresie stosowania odpowiedzialności karnej i administracyjnej w związku z art. 67 projektowanej ustawy. Wątpliwości wzbudza upodabnianie się procedury administracyjnej i karnej, a także nieprzemyślane kwalifikowanie zachowań karygodnych jako deliktów administracyjnych.

\footnotetext{
${ }^{1}$ Zob. <http://legislacja.rcl.gov.pl/docs//2/12304351/12465433/12465434/dokument324982.pdf> [dostęp: 8.07.2018).]

${ }^{2}$ Zob. m.in. Rodzynkiewicz (2018).

${ }^{3}$ Uzasadnienie do projektu ustawy o jawności życia publicznego z dnia 8 stycznia $2018 \mathrm{r}$. [dalej jako: u.p.u.j.ż.p.]: 70 .

${ }^{4}$ Zob. u.p.u.j.ż.p.
} 


\section{OBOWIĄZEK WPROWADZENIA WEWNĘTRZNYCH PROCEDUR ANTYKORUPCYJNYCH}

Wspomniany projektowany przepis art. 67 ust. 1 ustawy o jawności życia publicznego kreuje obowiązek stosowania wewnętrznych procedur antykorupcyjnych przez podmioty będące co najmniej średnim przedsiębiorca. Realizacja tego obowiązku ma na celu przeciwdziałanie przypadkom dokonywania przez osoby działające $\mathrm{w}$ imieniu lub na rzecz danego przedsiębiorcy enumeratywnie wymienionych $\mathrm{w}$ tym przepisie przestępstw o charakterze korupcyjnym. W przepisie dotyczącym blisko 20 tys. podmiotów gospodarczych działajacych w Polsce wskazuje się nadto, że przez procedury antykorupcyjne należy rozumieć środki organizacyjne, kadrowe i techniczne, które będą przeciwdziałać tworzeniu się korupcjogennego otoczenia (art. 67 ust. 2 projektowanej ustawy). Projektodawca, chcąc chyba ustrzec się wyjaśniania istoty praktyk antykorupcyjnych ignotum per ignotum, wskazuje przykładowe działania, które powinni podjać przedsiębiorcy w ramach wprowadzania tych praktyk. Zgodnie z treścią art. 67 ust. 2 projektowanej ustawy jest to m.in. opracowanie i wdrożenie kodeksu antykorupcyjnego przedsiębiorstwa podpisywanego przez każdego pracownika przedsiębiorcy, zapoznawanie nowo zatrudnianych osób z zasadami odpowiedzialności karnej za przestępstwa korupcyjne, czy też opracowanie i wdrożenie procedur informowania właściwych organów przedsiębiorcy o propozycjach korupcyjnych. Przepis ten jest jednak niepełny. Wskazać należy, że obowiązek wprowadzenia wewnętrznych procedur antykorupcyjnych z art. 67 ustawy dotyczy przedsiębiorców średnich. Stąd powstaje wątpliwość, czy projektodawca stanowi normę sankcjonującą w stosunku do wszystkich przedsiębiorców czy też tylko przedsiębiorcy średniego ${ }^{5}$.

\section{ROZDWOJENIE SYSTEMU KARANIA ZA NARUSZENIA PRZEPISÓW USTAWY O JAWNOŚCI ŻYCIA PUBLICZNEGO - ASPEKTY PROCEDURALNE I MATERIALNOPRAWNE}

Projekt ustawy o jawności życia publicznego przewiduje nadto uruchomienie konkretnych mechanizmów karania w razie niewywiązania się przez przedsiębiorców z nałożonych na nich obowiązków dotyczących stosowania procedur antykorupcyjnych. Zgodnie z art. 77 przedmiotowej ustawy, gdy osobie działającej w imieniu lub na rzecz przedsiębiorcy przedstawiono zarzuty popełnienia przestępstwa korupcyjnego, szef CBA wszczyna u danego przedsiębiorcy kontrolę. Jeżeli kontrola ta wykaże, że przedsiębiorca nie opracował procedur antykorupcyjnych lub ich nie stosuje, lub też zostaną one ocenione jako pozorne albo nieskuteczne, szef CBA sporządza wniosek o ukaranie

${ }^{5}$ Zwrócił na to uwagę Prezes UOKiK w pisemnej opinii z 6 listopada 2017 r., <http://legislacja.rcl.gov.pl/docs//2/12304351/12465413/12465416/dokument315790.pdf>: 11 [dostęp: 8.07.2018]. 
przedsiębiorcy. Kara, której podlega przedsiębiorca, jest sankcja administracyjna, tj. kara pieniężna w wysokości od 10 tys. do $10 \mathrm{mln}$ złotych.

Należy zwrócić uwagę na pewne rozszczepienie proceduralne postępowań $\mathrm{w}$ przedmiocie wymierzenia tych kar. Z jednej strony procedura zbliżona jest do postępowania mandatowego, zgodnie bowiem z art. 77 ust. 6 i 7 projektowanej ustawy, jeżeli przedsiębiorca nie uiści dobrowolnie w ciagu 30 dni kwoty wymierzonej mu kary pieniężnej, Szef CBA kieruje wniosek o ukaranie do Prezesa UOKiK. Z drugiej strony Prezes UOKiK ma wydać decyzję o ukaraniu, jednakże ustalenia z kontroli oraz wysokość wnioskowanej przez szefa CBA kary są dla niego wiążące. Istotne jest to, że sprawy te mają być badane według procedury karnej, ale same kary mają być wymierzane według procedury administracyjnej. Powoduje to, że strona ukarana podlega karom tak znaczacym jak w sprawach karnych, jednakże do wymierzenia kary jest stosowana procedura administracyjna, która znacząco odbiega od procedury karnej. Jest to bardzo istotne pod względem gwarancji proceduralnych w procedurze administracyjnej nie ma bowiem chociażby takich instytucji, jak domniemanie niewinności czy obrońca z urzędu'.

Krytycznie należy także odnieść się do zaproponowanej procedury nakładania kar w postępowaniu prowadzonym przez szefa CBA, który mógłby „zaproponować" sprawcy karę. Jeśli ten nie zapłaci jej dobrowolnie, sprawa zostanie skierowana do Prezesa UOKiK, który jednak będzie miał za zadanie tylko ukaranie firmy, bazując na ustaleniach CBA. Organ administracji publicznej traktowany jest jako egzekutor kar wymierzanych przez CBA. Taka procedurę kwestionuje także Prezes UOKiK, wskazując, że należy się zastanowić, czy jest ona zasadna z punktu widzenia efektywności i sprawności ze względu na tryb postępowania, a także czy Prezes UOKiK jest organem właściwym dla kwestii antykorupcyjnych ${ }^{7}$. Idąc dalej, zastanowić się należy, czy skoro mamy do czynienia z możliwością ukarania przez Szefa CBA na kształt mandatu karnego, to w przypadku jego nieprzyjęcia postępowanie nie powinno mieć charakteru sprawy karnej, a nie administracyjnej.

Zwrócić też należy uwagę na surowość kar przewidzianych w komentowanym projekcie ustawy. Kwestię tę dostrzegła również Krajowa Rada Sadownictwa, która w swojej opinii do projektu ustawy zauważyła, że kary proponowane przez projektodawcę w rozdz. 11 (dotyczącym odpowiedzialności za naruszenie przepisów ustawy) sa zbyt wysokie i nieadekwatne do stopnia i rozmiaru naruszeń ${ }^{8}$. Co do nieprawidłowości nadmiernej eksploatacji funkcji represyjnej przez administracyjne kary pieniężne wypowiadał się wielokrotnie RPO, wskazując, że są one często nieproporcjonalne do stopnia naruszenia prawa, co godzi w prawa człowieka ${ }^{9}$. Nakładanie wielomilionowych kar

\footnotetext{
${ }^{6}$ Szerzej: Staniszewska (2017): 309 i n.; Kruk (2013): 235; Wincenciak (2008): 167 i n.

${ }^{7}$ Zwrócił na to uwagę Prezes UOKiK w pisemnej opinii z 6 listopada 2017 r., <http://legislacja. rcl.gov.pl/docs//2/12304351/12465413/12465416/dokument315790.pdf>: 11-12 [dostęp: 8.07.2018].

${ }^{8}$ Opinia Krajowej Rady Sądownictwa z 6 grudnia 2017 r.: 3 <http://www.krs.pl/admin/files/ opinie-i-stanowiska/171206\%20020124.pdf> [dostęp: 8.07.2018].

9 Pisma RPO: z 4 stycznia 2013 do Ministra Transportu, Budownictwa i Gospodarki Morskiej, RPO 691806 V/12/GM, <http:// www.pigtsis.pl /content/files/ 15/public /Pismo _ RPO _ do
} 
w trybie postępowania administracyjnego budzi uzasadnione zastrzeżenia, ponieważ ustawodawca, po raz kolejny kwalifikując zachowania bezprawne jako delikty administracyjne, pomija zupełnie ich cel, funkcje i charakter ${ }^{10}$. Jest to bardzo szkodliwa praktyka polegająca na rzeczywistym zrównywaniu odpowiedzialności administracyjnej z odpowiedzialnością karna. Takie działania legislacyjne sprawiaja, że obecnie można już wskazywać na swego rodzaju prawo administracyjno-karne ${ }^{11}$. Wyraźnym celem ustawodawcy jest zastępowanie odpowiedzialności karnej i wykroczeniowej odpowiedzialnością administracyjna, która jest zasadniczo tańsza i szybsza aniżeli postępowanie karne, choć mniej gwarancyjna.

Podkreślić należy, że odpowiedzialność za delikt administracyjny, zagrożony karą pieniężna, powinna być zarezerwowana wyłącznie dla zachowań bezprawnych, które posiadają określone cechy, tj.: a) godzą w dobra zbiorowe istotne z punktu widzenia interesu społecznego, b) ich społeczna szkodliwość czynu ma mniejszy ładunek aniżeli w przypadku wykroczeń i przestępstw; c) sa moralnie ambiwalentne; d) ich celem jest zapewnienie realizacji obowiązków administracyjnoprawnych, a nie wyrządzenie dolegliwości; e) ich istota polega na samym naruszeniu prawa bez konieczności ustalania winy; d) ich wysokość jest powiązana z wyrządzoną szkoda. Tymczasem w niniejszym projekcie ustawodawca pomija te warunki, a nadto nadaje kompetencje organom do ustalenia wysokości kary z dużą dozą dyskrecjonalności. Zauważyć należy, że wymierzającymi kary będą organy funkcjonujące $\mathrm{w}$ ramach ustroju państwa, a nie bezstronne i niezawisłe sądy, może to doprowadzić do wymierzania kar nieproporcjonalnych, narażających podmioty gospodarcze na utratę płynności finansowej, a nawet zakończenie działalności gospodarczej z tych względów. Nawet inicjowanie postępowania odwoławczego i sądowego nie jest zabezpieczeniem wystarczającym do ochrony interesu prawnego przedsiębiorcy. Standard ochrony jednostki w tych postępowaniach, w których istnieje zagrożenie represyjną i dolegliwa sankcja, powinien być taki jak w postępowaniu karnym. Poddanie tych spraw pod rygor postępowania administracyjnego ułatwi być może procedowanie, co jest niewątpliwie celem ustawodawcy, ale kosztem ochrony praw podmiotów karanych. Przeciwstawić się należy także nadmiernemu zbliżaniu odpowiedzialności administracyjnej do odpowiedzialności karnej, niweczy to bowiem cel sankcji administracyjnych, którym jest przede wszystkim efektywne zapewnienie przestrzegania dyrektyw administracyjnych.

Podkreślić należy, że regulację rozdz. 11 projektowanej ustawy o jawności życia publicznego należy także rozważyć pod kątem współobowiązywania z działem IVA: „Administracyjne kary pieniężne”, zawartym w k.p.a. Wskazać należy, że projektodawca w art. 80 ustawy o jawności życia publicznego stanowi, że do kar zawartych $\mathrm{w}$ art. $69,72,73$ i 75 stosuje się dział IVA k.p.a.

\footnotetext{
_Ministra_TBiGM4012013.Pdf> [dostęp: 31.03.2017] oraz z 29 stycznia 2013 do Ministra Administracji i Cyfryzacji, RPO 722886-V/2013/PM, <http://www.Sprawy-generalne.brpo.gov.pl/ pdf/2013/01/722886/1698149.pdf> [dostęp: 31.03.2017].

${ }_{10}$ Przybysz (2011): 170.

${ }^{11}$ Szumiło-Kulczycka (2004): 10.
} 
Większość administracyjnych kar pieniężnych wskazanych w rozdz. 11 projektowanej ustawy stanowi kary względnie oznaczone, co powoduje, że organy korzystaja z luzu decyzyjnego co do ich wymiaru. W związku z tym konieczne jest przeanalizowanie, czy projektowana ustawa zawiera samodzielną regulację przesłanek wymiaru tychże kar, czy też stosuje się regulację art. 189d k.p.a. Zgodnie z art. 189a $§ 2$ k.p.a. w przypadku uregulowania w przepisach odrębnych przesłanek wymiaru administracyjnej kary pieniężnej, przepisów niniejszego działu $\mathrm{w}$ tym zakresie nie stosuje się. Zatem $\mathrm{w}$ stosunku do kar wymierzanych zgodnie z projektowanym rozwiąaniem, k.p.a. nie miałby być stosowany do przesłanek ich wymiaru, uregulowanych odrębnie w art. 69 ust. 3 , art. 72 ust. 2 , art. 77 ust. 5 projektowanej ustawy. Niemniej pozostaje wiele watpliwości pod adresem regulacji odrębnych, które wyłączają stosowanie art. 189 d k.p.a., a ich katalog jest znacząco węższych aniżeli ten zawarty w art. 189 d k.p.a.

W kontekście niniejszych rozważań ważny jest art. 77 ust. 5 projektowanej ustawy, który stanowi o przesłankach miarkowania kary przez szefa CBA. Organ ten bierze pod uwagę nieprawidłowości, wysokość korzyści uzyskanej przez przedsiębiorcę, sytuację majątkową przedsiębiorcy oraz okoliczności łagodzace lub obciążające, które wystapiły w sprawie. Zauważyć należy, że już pod kątem legislacyjnym można mieć zastrzeżenia co do sposobu sformułowania tych przesłanek, ponieważ zawierają one zwroty niedookreślone, takie jak: „okoliczności łagodzące lub obciążające”, co wzmaga dyskrecjonalność w wymierzaniu administracyjnej kary pieniężnej. Ogólne brzmienie projektowanego przepisu nadaje szeroką uznaniowość szefowi CBA ustalającemu wysokość kary, co niweczy de facto w całości cel wprowadzenia przepisów stanowiacych przesłanki wymiaru kary do k.p.a. z uwagi na trudne do kontroli sądowej uprawnienia dyskrecjonalne organów. W praktyce może oznaczać to wymierzanie bardzo wysokich kar bez realnej możliwości ich kwestionowania przez stronę ukaraną.

Nadto sposób formułowania owych przesłanek jest właściwy dla spraw karnych, w sprawach administracyjnych bowiem sytuacja finansowa podmiotu karanego jest brana pod uwagę jedynie w przypadku osób fizycznych, a nie przedsiębiorców, co ukazuje art. 189d pkt 7 k.p.a., który jest zgodny z aksjologią tychże kar. Być może ustawodawca, projektując taką przesłankę wymiaru kary, chciał złagodzić konsekwencje braku obowiązywania zakazu multiplikacji kar, jak i zakazu ne bis in idem.

Odnosząc się natomiast do samych przesłanek wymiaru administracyjnej kary pieniężnej za naruszenie obowiązku wprowadzenia i realizacji procedur antykorupcyjnych, wskazać należy, że są one niezmiernie rozbudowane. Jednakże nie zawierają regulacji związanej z miarkowaniem kary w przypadku uprzedniego ukarania za to samo zachowanie jako za przestępstwo, przestępstwo skarbowe, wykroczenie lub wykroczenie skarbowe.

W projektowanej ustawie zawarta została także regulacja odstapienia od ukarania - art. 77 ust. 16. Przepis ten stanowi instytucję fakultatywnego odstapienia od wymierzenia kary, gdy naruszenie wewnętrznych procedur antykorupcyjnych było nieznaczne lub nie miało wpływu na popełnienie zarzucanych czy- 
nów przez osobę, która działała w imieniu lub na rzecz przedsiębiorcy, realizując zawartą z nim umowę. Wątpliwości jednak budzi fakt, że organem właściwym do podjęcia rozstrzygnięcia $\mathrm{w}$ przedmiocie odstapienia jest Prezes UOKiK, a pomimo wystapienia takich przesłanek Szef CBA takiej kompetencji już nie posiada. Zatem rozważyć należy, czy zgodnie z art. 80 projektowanej ustawy, w procedurze toczącej się przed Szefem CBA znaleźć powinno zastosowanie rozwiązanie z art. $189 f$ k.p.a., który to $\mathrm{w} \S 1$ stanowi obligatoryjne przesłanki odstapienia od nałożenia administracyjnej kary pieniężnej, a w § 2 fakultatywne, czy też ustawodawca celowo pozbawia możliwości odstapienia od nałożenia kary stronę, która wyraża wolę jej uiszczenia. Z pewnością wątpliwa jest słuszność rozwiązania pozwalającego na odmienne traktowanie podmiotów jedynie ze względu na to, jaki organ rozpoznaje ich sprawę. Regulacja ta wymaga zmiany w ten sposób, że w przypadku wystapienia przesłanki odstapienia od wymierzenia kary, instytucję tę może zastosować także Szef CBA. Taka regulacja pozwoliłaby uniknąć stronie odpowiedzialnej długotrwałej procedury administracyjnej, a nadto służyłaby zwiększeniu efektywności postępowań tego rodzaju.

Natomiast regulacja przesłanek odstapienia od wymierzenia kary w art. 77 ust. 16 projektowanej ustawy jako normy szczególnej względem art. 189 f k.p.a. powoduje, że w stosunku do ukaranych na podstawie art. 77 projektowanej ustawy nie obwiązuje zakaz multiplikacji administracyjnych kar pieniężnych, ani zakaz ne bis in idem. Nadto art. 77 ust. 2 projektowanej ustawy stanowiacy, że kary pieniężnej nie nakłada się, jeżeli postępowanie w sprawie popełnienia przestępstwa $\mathrm{z}$ art. 67 ust. 1 zostało już wszczęte na podstawie wcześniejszego zawiadomienia złożonego przez przedsiębiorcę, wyczerpuje regulacje związane z zakazem podwójnego karania w postępowaniach dotyczacych tych deliktów administracyjnych, z wyłączeniem art. $189 f \S 1$ ust. 2 k.p.a. Taka regulacja w przypadku zakazu zarówno multiplikacji kar, jak i podwójnego karania powinna zostać rozważona w kontekście gwarancji proceduralnych w sprawach o charakterze represyjnym. Sąd Najwyższy wprost wskazuje, że w sprawach z odwołania od decyzji Prezesa UOKiK i organów regulacji nakładajacych dolegliwe kary pieniężne stosować należy standardy obowiązujące w sprawach karnych ${ }^{12}$. Wyraźny postulat płynący z tego orzecznictwa zdaje się szczególnie istotny na tle analizowanych regulacji projektu ustawy o jawności życia publicznego.

\section{CELOWOŚĆ WPROWADZENIA DELIKTU ADMINISTRACYJNEGO ZAGROŻONEGO ADMINISTRACYJNĄ KARĄ PIENIĘŻNĄ}

Analizowane rozwiązania projektu ustawy o jawności życia publicznego dotyczące nakładanego na przedsiębiorców obowiązku stosowania praktyk antykorupcyjnych stykają się z prawem karnym w jeszcze jednym punkcie.

${ }^{12}$ Wyroki SN: z 25 października 2017, III SK 38/16, Lex nr 2435635; z 14 kwietnia 2010 r., III SK 1/10, Lex nr 1037765. 
Kontrolę przedsiębiorcy uruchamiać ma przecież, w myśl brzmienia art. 77 ust. 3 projektowanej ustawy, postawienie zarzutu popełnienia przestępstwa korupcyjnego osobie działającej w imieniu lub na rzecz przedsiębiorcy. Bardzo wyraźnie trzeba podkreślić, że projektowane przepisy nie wymagają prawomocnego skazania takiej osoby, a więc nie jest konieczne udowodnienie jej przed sądem przez organy ściagania zarzucanego czynu, nie jest też konieczne sądowe stwierdzenie zachodzenia wszystkich przesłanek odpowiedzialności karnej. Wystarczy samo postawienie zarzutów. Oprócz tego, że takie rozwiązanie prawne może być furtką do różnych nadużyć, to nieodparcie nasuwa się pytanie, jakie powinny być skutki dla wszczęcia i prowadzenia kontroli u przedsiębiorcy, a w konsekwencji dla ewentualnie wymierzonej mu kary, jeśli np. osoba, której postawienie zarzutów uruchomiło całą machinę przeciwko przedsiębiorcy, zostanie $\mathrm{w}$ toku procesu karnego uniewinniona. Postawione jej zarzuty, które są zasadniczą przesłanką wszczęcia kontroli przedsiębiorcy, okazuja się w przypadku uniewinnienia nie mieć żadnych podstaw. Tym samym należałoby stwierdzić brak podstawy faktycznej i prawnej do wszczęcia kontroli, prowadzenia jej i zakończenia nałożeniem administracyjnej kary pieniężnej. Zauważyć przy tym należy, że przeważnie postępowanie karne przeciwko osobie działającej w imieniu lub na rzecz przedsiębiorcy kończyłoby się zapewne już po kontroli przedsiębiorcy i wymierzeniu mu kary. Nieodparcie nasuwa się więc pytanie o możliwość zawieszenia lub wznowienia postępowania w sprawie wymierzenia kary przedsiębiorcy. Próżno jednak w projektowanej ustawie o jawności życia publicznego szukać stosownych regulacji w tym zakresie. Dołączone do projektu ustawy uzasadnienie analizowanych przepisów jest bowiem bardzo skape. W zasadzie streszczono w nim brzmienie poszczególnych artykułów dotyczących procedur antykorupcyjnych. Wskazano nadto, że opracowanie i wdrożenie przedmiotowych procedur będzie stanowić istotny punkt wyjścia w procesie zapobiegania korupcji oraz przełoży się na transparentność życia publicznego ${ }^{13}$. Biorąc pod uwagę stopień represyjności projektowanego brzmienia art. 77 analizowanej ustawy, uzasadnienie to jawi się jako niewystarczające. Raz jeszcze trzeba zwrócić uwagę, że górna granica kary pieniężnej wymierzanej przedsiębiorcy jest dość wysoka, jest to $10 \mathrm{mln}$ złotych. Dodatkowo, zgodnie z projektowanym brzmieniem art. 78 ust. 1, przedsiębiorca, któremu wymierzono karę, przez okres 5 lat nie może ubiegać się o uzyskanie zamówienia publicznego. Zauważyć należy, że w praktyce, w niektórych przypadkach, sankcje zastosowane wobec przedsiębiorcy mogą na mocy projektowanej ustawy doprowadzić po prostu do jego upadłości. Ponownie nasuwa się zatem pytanie o wpływ możliwego uniewinnienia osoby działającej w imieniu lub na rzecz przedsiębiorcy na przebieg i wynik postępowania upadłościowego.

Oczywiście argumentować można, że postawienie zarzutów jednej z osób związanej z przedsiębiorca jest konieczna, ale nie jedyną przesłanką wymierzenia mu kary. W myśl projektowanej ustawy wymagane jest jeszcze stwierdzenie konkretnych nieprawidłowości w stosowaniu przez przedsiębiorcę pro-

\footnotetext{
${ }^{13}$ Zob. u.p.u.j.ż.p.
} 
cedur antykorupcyjnych. Tyle tylko, że nieprawidłowości te zostały w projekcie ustawy określone w sposób bardzo nieprecyzyjny. Zgodnie bowiem z zawartym w nim art. 77 ust. 1 wymierzenie przedsiębiorcy kary może być warunkowane tym, że stosowane przez niego procedury antykorupcyjne były pozorne lub nieskuteczne. Kiedy moga być one za takie uznane? Logiczna zdawałaby się odpowiedź, że prawdopodobnie wówczas, gdy jakaś osoba działająca w imieniu lub na rzecz przedsiębiorcy popełni jedno z przestępstw o charakterze korupcyjnym. Wracamy tu jednak do punktu wyjścia, tj. do kwestii tego, że postawienie zarzutów nie zawsze oznacza, że dana osoba rzeczywiście popełniła zarzucane jej przestępstwo. Ponadto nie można też wykluczyć sytuacji, że do popełnienia przestępstwa korupcyjnego przez osobę związaną z przedsiębiorstwem może dojść pomimo tego, że w pełni prawidłowo stosowano w nim odpowiednie procedury antykorupcyjne.

Trzeba się też wreszcie zastanowić, czy projektowane w ustawie o jawności życia publicznego regulacje dotyczące obowiązku przedsiębiorców w zakresie stosowania praktyk antykorupcyjnych i ich odpowiedzialności za uchybienie temu obowiązkowi w ogóle sa potrzebne, aby egzekwować odpowiedzialność przedsiębiorców w związku z przestępstwami korupcyjnymi osób powiązanych z przedsiębiorstwem. Trzeba bowiem zwrócić uwagę na istniejąca już od kilkunastu lat ustawę o odpowiedzialności podmiotów zbiorowych za czyny zabronione pod groźbą kary. Przepisy tej ustawy przewidują możliwość przypisania quasi-karnej odpowiedzialności za określone przestępstwa, w tym także korupcyjne, osobom prawnym i innym jednostkom organizacyjnym niemajaccym osobowości prawnej, którym odrębne przepisy przyznają zdolność prawną. Warunkiem przypisania tej odpowiedzialności jest - w myśl art. 3 ustawy o odpowiedzialności podmiotów zbiorowych - dopuszczenie się czynu zabronionego przez osobę fizyczną powiązaną z podmiotem zbiorowym na jeden ze sposobów określonych w tym przepisie oraz odniesienie lub możliwość odniesienia przez podmiot zbiorowy z tego czynu korzyści, chociażby niemajątkowej. Karą wymierzaną osobie prawnej na podstawie tej ustawy jest kara pieniężna, a nadto sąd może orzec również zakaz ubiegania się o zamówienia publiczne.

Faktem jest, że ustawa o odpowiedzialności podmiotów zbiorowych za czyny zabronione pod groźba kary przez ostatnie lata nie miała szerokiego zastosowania (w $2015 \mathrm{r}$. było to tylko 14 spraw). Wspomina się o tym zreszta w uzasadnieniu projektu ustawy o jawności życia publicznego $0^{14}$. Ministerstwo Sprawiedliwości pracuje jednak nad nową ustawą regulująca odpowiedzialność podmiotów zbiorowych za czyny zabronione pod groźba kary. W projekcie tej ustawy z 1 października 2018 r. poszerzono podstawy odpowiedzialności podmiotów zbiorowych. Objęte tą odpowiedzialnością mają zostać również zachowania uznane za zachowania własne podmiotów zbiorowych wyczerpujace znamiona czynu zabronionego. Ponadto nowa ustawa zakłada rezygnację z wymogu uprzedniego uzyskiwania wyroku skazującego osobę fizyczną powiąaną z podmiotem zbiorowym. Nie będzie nawet konieczne ustalenie konkretnej osoby fizycznej jako sprawcy przestępstwa. Zmianie mają ulec również

14 Zob. u.p.u.j.ż.p. 
dolna i górna granica grożącej podmiotowi zbiorowemu kary, przy czym górna granica ma wynosić $30 \mathrm{mln}$ złotych (obecnie jest to $5 \mathrm{mln}$ ) ${ }^{15}$.

Przesłanki odpowiedzialności administracyjnej przedsiębiorców kreowanej przez komentowane przepisy projektu ustawy o jawności życia publicznego w znacznym stopniu pokrywają się więc z przesłankami odpowiedzialności quasi-karnej podmiotów zbiorowych opartej na nowej wersji ustawy o odpowiedzialności podmiotów zbiorowych za czyny zabronione pod groźba kary. Kary, które można orzec na podstawie tych ustaw, są również tożsame. Uzasadnione zatem stają się wątpliwości, czy projektowane przepisy ustawy o jawności życia publicznego nie dublują projektowanych przepisów ustawy o odpowiedzialności podmiotów zbiorowych za czyny zabronione pod groźbą kary. Oczywiście wskazywać można, że pierwsza tworzy odpowiedzialność administracyjna, druga - quasi-karna. Jedna i druga maja jednak charakter represyjny ${ }^{16}$.

Konieczność gwarantowania standardów właściwych dla spraw karnych do deliktów administracyjnych, które to nie mają charakteru właściwego karom administracyjnym, tj. porządkowo-dyscyplinującego, ale są karami wyłącznie represyjnymi ${ }^{17}$, rodzi konieczność zadania pytania o przestrzeganie zasady ne bis in idem, która zakazuje dwukrotnego karania za ten sam czyn.

Coraz częściej bowiem zwraca się uwagę, że zasady tej nie należy ograniczać jedynie do wymierzania kar w reżimie karnym, czy quasi-karnym, ale powinna ona dotyczyć również kar o charakterze administracyjnym ${ }^{18}$. W tym

${ }^{15}$ Zob. projekt ustawy z 25 maja 2018 r., <http://legislacja.rcl.gov.pl/projekt/12312062/kata$\log / 12511889 \# 12511889>$ [dostęp: 8.07.2018].

${ }^{16}$ Represyjny charakter odpowiedzialności quasi-karnej wykreowanej w ustawie o odpowiedzialności podmiotów zbiorowych za czyny zabronione pod groźbą kary jako szczególny rodzaj odpowiedzialności karnej nie wymaga szerszego wyjaśnienia. W uznaniu odpowiedzialności administracyjnej przedsiębiorcy na podstawie art. 77 projektowanej ustawy o jawności życia publicznego za odpowiedzialność o charakterze represyjnym pomocne mogą być kryteria zaproponowane przez Błachnio-Parzych - zob. Błachnio (2016): 88; wskazuje ona, że w celu rozstrzygnięcia, czy dana odpowiedzialność ma charakter represyjny, należy uwzględnić oprócz kryterium formalnego (tj. miejsca regulacji odpowiedzialności), również dwa inne kryteria - stopień dolegliwości sankcji oraz jej cel. Analizowane przepisy ustawy o jawności życia publicznego pozwalają wymierzyć przedsiębiorcy karę pieniężną w wysokości od 10 tys. do $10 \mathrm{mln}$ złotych. Dodatkowo ukarany przedsiębiorca przez okres 5 lat nie może ubiegać się o uzyskanie zamówienia publicznego. Dolegliwość przedmiotowej sankcji, która skutkować wręcz może zakończeniem działalności danego przedsiębiorcy, z pewnością może być uznana za znaczna. Nadto zdaje się, że celem tej sankcji jest represja. Trudno dopatrzeć się w nim chociażby elementów prewencyjnych.

17 Kasiński (2001): 281.

${ }^{18} \mathrm{~W}$ świetle zarysowanej na kanwie analizowanych projektów ustaw sytuacji zbiegu odpowiedzialności administracyjnej i karnej należy zwrócić uwagę na wyrok TK z 20 czerwca 2017 r., P 124/15, Lex nr 2306392. W uzasadnieniu tego orzeczenia TK wprost wskazał, że: „[...] zakaz podwójnego (wielokrotnego) karania obejmuje nie tylko sprawy i postępowania uznane za karne przez ustawy zwykłe (prawo karne sensu stricto), lecz także sprawy i postępowania niemajace formalnie karnoprawnego charakteru, o ile wiążą się ze stosowaniem środków w istocie represyjnych (prawo karne sensu largo). Zakaz podwójnego (wielokrotnego) karania musi zatem być brany pod uwagę zarówno w wypadku zbiegu dwóch (kilku) kar kryminalnych w rozumieniu ustawowym, jak i w razie zbiegu sankcji określonych w przepisach karnych oraz sankcji przewidzianych w innych przepisach prawa publicznego ( $\mathrm{w}$ tym w przepisach prawa administracyjnego), jeżeli przewidują one formy odpowiedzialności prawnej mające cechę represyjności". Najnowsze orzeczenie TSUE z 20 marca 2018 r., C 537/16, Lex nr 2459064, wskazuje, że wykładni art. 50 Karty praw 
kontekście szczególnie istotne staje się brzmienie art. 4 projektu nowej ustawy o odpowiedzialności podmiotów zbiorowych za czyny zabronione pod groźbą kary. Zgodnie bowiem z tym przepisem odpowiedzialność albo brak odpowiedzialności podmiotu zbiorowego na zasadach określonych w niniejszej ustawie nie wyłącza odpowiedzialności cywilnej za wyrządzona szkodę, odpowiedzialności administracyjnej ani indywidualnej odpowiedzialności prawnej sprawcy czynu zabronionego. Wydaje się więc, że bardzo prawdopodobna i w pełni dopuszczalna może okazać się sytuacja, w której dany przedsiębiorca ze względu na dopuszczenie się przestępstwa o charakterze korupcyjnym przez jednego ze swoich pracowników zostanie ukarany sankcją administracyjną na podstawie projektowanej ustawy o jawności życia publicznego za niewywiązanie się z obowiązku stosowania wewnętrznych procedur antykorupcyjnych oraz sankcją quasi-karną na podstawie obecnej czy też dopiero projektowanej ustawy o odpowiedzialności podmiotów zbiorowych za czyny zabronione pod groźba kary. Obie sankcje będą de facto kara pieniężną opiewająca potencjalnie na dość wysoką kwotę i obie będą wyrazem zastosowania wobec danego przedsiębiorcy odpowiedzialności represyjnej, dwukrotnie. Krótko mówiąc, dojdzie do sytuacji zbiegu odpowiedzialności administracyjnej i quasi-karnej mogącej nadwyrężać zasadę ne bis in idem.

$\mathrm{Z}$ uwagi na regulacje odrębne projektowanej ustawy w zakresie dyrektyw wymiaru kary, jak i przesłanek odstapienia od wymierzenia administracyjnej kary pieniężnej zgodnie z art. 189a k.p.a. przepisów art. 189d i art. 189f nie będzie można zastosować.

Tymczasem realizowanie $\mathrm{w}$ pewnym stopniu zasady ne bis in idem także $\mathrm{w}$ stosunku do administracyjnych kar pieniężnych umożliwiać miała regulacja Kodeksu postępowania administracyjnego zawarta w art. $189 \mathrm{f} \S 1$ pkt 2 . Wymieniony przepis stanowi, że organ administracji publicznej w drodze decyzji odstępuje od nałożenia administracyjnej kary pieniężnej i poprzestaje na pouczeniu, jeżeli za to samo zachowanie prawomocną decyzją na stronę została uprzednio nałożona administracyjna kara pieniężna przez inny uprawniony organ administracji publicznej lub strona została prawomocnie ukarana za wykroczenie lub wykroczenie skarbowe, lub prawomocnie skazana za przestępstwo lub przestępstwo skarbowe i uprzednia kara spełnia cele, dla których miałaby być nałożona administracyjna kara pieniężna.

W przypadku zatem pociagnięcia do odpowiedzialności za dany czyn na podstawie ustawy o odpowiedzialności podmiotów zbiorowych za czyny zabronione pod groźbą kary - postępowanie administracyjne zmierzające do wydania administracyjnej kary pieniężnej powinno się zakończyć odstapieniem od jej nałożenia i pouczeniem. Jednakże możliwe są także sytuacje, w których

podstawowych Unii Europejskiej należy dokonywać w ten sposób, że przepis ten stoi na przeszkodzie przepisom krajowym, które dopuszczają możliwość prowadzenia postępowania w sprawie nałożenia administracyjnej kary pieniężnej o charakterze karnym wobec osoby, która popełniła czyn zabroniony w analizowanej sprawie, był to czyn polegający na dokonywaniu manipulacji na rynku, za który to czyn owa osoba została już skazana prawomocnym wyrokiem sądu karnego, o ile tylko kara orzeczona w owym wyroku skazującym, mając na uwadze szkodliwość społeczna popełnionego przestępstwa, stanowi skuteczna, proporcjonalną i odstraszającą reakcję na nie. 
dojdzie do wszczęcia postępowania karnego już po wymierzeniu administracyjnej kary pieniężnej, a wówczas kara kryminalna może zostać wymierzona. Niewątpliwie zakaz podwójnego karania powinien zostać uregulowany także w projektowanej ustawie, tak by w praktyce nie dochodziło do łamania zasady ne bis in idem, w stosunku do której wielokrotnie w związku ze sprawami o nałożenie kar administracyjnych i kryminalnych wypowiadał się rzecznik praw obywatelskich. Wystarczajacej regulacji nie stanowi w tym przedmiocie art. 77 ust. 2 projektowanej ustawy, albowiem jej art. 67 ust. 1 odnosi się tylko do przestępstw dotyczących średnich przedsiębiorców, a już takiego ograniczenia nie zawiera norma $\mathrm{z}$ art. 77 ust. 1 . Nadto art. 77 ust. 2 odnosi się do sytuacji, w których jako pierwsze wszczęte zostało postępowanie karne, podczas gdy nie chroni w żaden sposób przed podwójnym karaniem podmiotów, co do których w pierwszej kolejności wszczęto postępowanie o nałożenie administracyjnej kary pieniężnej.

\section{PODSUMOWANIE}

Podsumowując powyższe rozważania, należałoby stwierdzić, że projektowane przepisu ustawy o jawności życia publicznego regulujące obowiązki przedsiębiorcy $\mathrm{w}$ zakresie stosowania praktyk antykorupcyjnych oraz przewidujące za nienależyte wywiązanie się $\mathrm{z}$ tego obowiązu dotkliwe sankcje administracyjne wymagaja jeszcze pogłębionej analizy. Ich wejście życie w kształcie przedstawionym w projekcie ze stycznia 2018 r. prowadziłoby do powstania bardzo poważnych problemów i wątpliwości o charakterze proceduralnym (kwestia wpływu wyroku zapadłego w postępowaniu karnym na możliwość i zasadność ukarania przedsiębiorcy) czy też systemowym związanym z przyjętym reżimem odpowiedzialności. Dlatego też za zasadne należy uznać wstrzymanie procedowania projektu ustawy. Niewątpliwie uregulowana w art. 77 projektowanej ustawy administracyjna kara pieniężna za delikt administracyjny, który godzi w dobro chronione prawem karnym, jak i jego stopień karygodności in abstracto decydują o tym, że stanowi on czyn quasi-karny. Nawet jeżeli zróżnicowanie odpowiedzialności związanej z naruszeniami procedur antykorupcyjnych miałoby przekonujące uzasadnienie i zasadne byłoby przyjęcie odpowiedzialności administracyjnej, to zastosowanie do niej znaleźć powinien art. 2 Konstytucji RP. Ustawodawca, decydując się na zakwalifikowanie danego zachowania bezprawnego do deliktów administracyjnych, powinien pamiętać o respektowaniu zasad wynikających z tego przepisu Konstytucji RP (zwłaszcza zasady ne bis in idem) równości, jak i proporcjonalności.

Należy krytycznie ocenić szerokie stosowanie przez projektodawcę typów deliktów administracyjnych. Stanowi to obejście gwarancji wynikajacych z prawa karnego materialnego i procesowego. System proponowanych unormowań co do wysokości proponowanych sankcji, dyrektyw ich wymierzania, jak i podmiotów, którym powierzono kompetencje do ich stosowania, 
jest niespójny i wątpliwy w państwie demokratycznym. Za szczególnie rażące z punktu widzenia konstytucyjnych praw i wolności należy uznać wyposażenie organu ścigania, jakim jest Szef Centralnego Biura Antykorupcyjnego, w kompetencje do wymierzania administracyjnych kar pieniężnych w drodze decyzji administracyjnej. Budzi to poważne wątpliwości, zwłaszcza w przypadku karania osób fizycznych, w dodatku z możliwością zaopatrzenia decyzji w rygor natychmiastowej wykonalności, dlatego trudno mówić o zapewnieniu podstawowych gwarancji podmiotom karanym.

Wskazać zatem należy, że przyświecające projektodawcy cele - wzmocnienie ochrony państwa przed korupcją - zasługują na aprobatę. Jednakże w obecnej postaci projekt budzi zasadne wątpliwości zarówno pod względem legislacyjnym, jak i merytorycznym. Projekt ustawy w obecnym kształcie nie odpowiada standardom konstytucyjnym, a w zakresie wymogów spójności prawa i kanonów dobrej legislacji wymaga fundamentalnego przepracowania proponowanego tekstu normatywnego.

Magdalena Kowalewska-Eukuć

Uniwersytet Szczecinski

magdalena.kowalewska-lukuc@usz.edu.pl

https://orcid.org/0000-0002-6663-3674

Lucyna Staniszewska

Uniwersytet im. Adama Mickiewicza w Poznaniu

lucynast@amu.edu.pl

https://orcid.org/0000-0003-3457-0901

Błachnio-Parzych, A. (2016). Zbieg odpowiedzialności karnej i administracyjno-karnej jako zbieg reżimów odpowiedzialności represyjnej. Warszawa.

Kasiński, M. (2001). Ekspansja represyjnych funkcji administracji publicznej jako zagrożenie demokratycznego państwa prawa. Rocznik Nauk Prawnych 1: 277-298.

Kruk, E. (2013). Sankcja administracyjna. Lublin.

Przybysz, P. (2011). Funkcje sankcji administracyjnych, [w:] M. Stahl, R. Lewicka, M. Lewicki (red.), Sankcje administracyjne. Warszawa: 161-171.

Rodzynkiewicz, M. (2018). Projekt ustawy o jawności życia publicznego, czyli jak utrudnić działanie przedsiębiorcom. Rzeczpospolita 5 luty 2018.

Staniszewska, L. (2017). Administracyjne kary pieniężne. Studium z zakresu prawa administracyjnego materialnego i procesowego. Poznań.

Szumiło-Kulczycka, D. (2004). Prawo administracyjno-karne. Kraków.

Wincenciak, M. (2008). Sankcje w prawie administracyjnym i procedura ich wymierzania. Warszawa.

\section{THE OBLIGATION FOR ENTREPRENEURS TO APPLY ANTI-CORRUPTION PROCEDURES IN THE LIGHT OF THE DRAFT ACT ON THE TRANSPARENCY OF PUBLIC LIFE}

$$
\text { Sum mary }
$$

The article focuses on the issue of punishment in the draft bill of the Act on the Transparency of Public Life. The adoption of the concept of administrative sanctions for violation of the law is a matter of concern. Corruption, due to the fact it is culpable and blameworthy, has been penalized by criminal law for years. The new sanctioning procedure is related to the need to penalize 
collective entities more effectively and efficiently. However, there are undoubtedly already regulations in criminal law that allow such entities to be held accountable. The new amendment will create an additional regime of quasi-criminal liability, which will clearly not guarantee effective and quick punishment. Aside from the amount of the sanctions, which can reach a maximum of PLN10 million, the procedure for imposing penalties is also questionable. Firstly, the Head of the Central Anti-corruption Bureau (CBA) will impose a fine on the enterprise. If the entrepreneur does not pay this fine voluntarily, an application to hold the enterprise liable will be forwarded to the President of the Office of Competition and Consumer Protection (UOKiK). However, under new regulations the position of the President is reduced to the role of an enforcer. Furthermore, anti-corruption procedures clearly fall under the competence of the Head of CBA, not of the President of UOKiK, hence the structure adopted in the Act is incomprehensible. The conclusion of the article is that it is necessary for the authors of the Act to reflect on the model of punishment for violating anti-corruption procedures.

Keywords: liability of collective entities; administrative fines; anti-corruption procedure 
